DOI https://doi.org/10.32837/app.v0i65.320

UDC 341.1

\author{
N. M. Oleksiuk \\ ORCID ID: https://orcid.org/0000-0001-9726-9767 \\ Master of Laws, Attorney at Law \\ "Peritus Consulting" LLC
}

\title{
PRINCIPLES OF PEACEKEEPING IN NATO'S LEGAL FRAMEWORK
}

Emphasis of the problem. In modern times of vulnerable environment, security crises, existence of full range of conventional and non-conventional threats to international peace and society, it is crucially important to find out the most effective solutions of challenges through the effective institutions. NATO as one of such institutions is constructed for tackling the security issues that the Euro-Atlantic area is facing. In limine, it ought to be noted that the legal framework of either UN and NATO peace operations is not written anywhere in the UN Charter or the North Atlantic Treaty. Academic debate on this issue can be seen when Hitoshi Nasu argues that it can be construed as a provisional measure under Article 40 of the UN Charter (Nasu, 2009, p.35), whereas Christine Gray argues that «the debate seems to be without practical significance» (Gray, 2018, p. 262). Nevertheless, the point is that the specific rules on peace operations are not provided or regulated by the UN Charter. Dieter Fleck notably insisted that an absence of pre-existing legal rules may negatively affect the success of an operation designed to maintain or restore international peace and security. When operations are undertaken based on doubtful legality, the rule of law as a condition for stable peace is in danger of being jeopardized. Similarly, the conduct of a mission itself may be disturbed by legal uncertainties as to the mandate, the command system, and existing rights and obligations. It is for these reasons that legal principles and rules should be given closer attention (Fleck, 2014, p. 219). Hence, taking into account that in the past several decades NATO provided huge number of peacekeeping operations and still providing such, analysis and emphasis of its principles of peacekeeping is essential in given research.

Analysis of the latest researches and publications. Despite the UN Charter and the North Atlantic Treaty, which are fundamental for current research, the most important sources of present article consist of scholar literature and acts of international organizations i.e. UNSC resolutions and NATO's normative acts, which are relevant to the topic of the article. In general, it ought to be noted that the issues on the principles of peacekeeping were researched by various scholars: Lindsey Cameron, Yoram Dinstein, Dieter Fleck, Christine Gray, Lise Morje Howard, Hitoshi Nasu, Osamu Yoshida, Tarcisio Gazzini and others. Generally speaking, given researches were based on the relevant experience of peacekeeping activities led by NATO mostly since 1992 when in May, 1992 the first peacekeeping operation of NATO took place under the UNSC sanction. Also it should be added that there are other essential sources on the issue: reports of the UN Panel on peacekeeping and General Principles and Guidelines of the UN on peacekeeping.

Aim of current article is to examine the principles of peacekeeping applied by NATO and give a proper evaluation to each of them in divertive coherence of scholar views on given issue and the relevant legal practice of the UN and NATO as well.

Presentation of the general material. According to the principles and guidelines of the UN peacekeeping, the practice of United Nations peacekeeping has evolved significantly over the past six decades, three basic principles have traditionally served and continue to set United Nations peacekeeping operations apart as a tool of maintaining international peace and security: (i) Consent of the parties; (ii) Impartiality; (iii) Non-use of force except in self-defence and defence of the mandate (Principles and Guidelines, 2008, par. 61).

These principles are inter-related and mutually reinforcing. It is important that their meaning and relationship to each other are clearly understood by all those involved in the planning and conduct of United Nations peacekeeping operations, so that they are applied effectively. Taken together, they provide a navigation aid, or compass, for practitioners both in the field and at United Nations Headquarters (Principles and Guidelines, 2008, par. 62). 
Actually, it has to be noted that current principles of peacekeeping formulated in the UN document were first set down by former UN Secretary-General Dag Hammarskjøld at the time of the creation of the first peace operation and have remained touchstones of legality and legitimacy ever since, despite the fact that they have not been interpreted in a consistent manner over the years (Cameron, 2017, p. 61).

Being of more practical sense and related to military activities, the NATO joint doctrines on peace operations also mention those three fundamental principles (Allied Joint Doctrine, 2010; Allied Joint Doctrine, 2014).

Generally, those three principles of peacekeeping are followed by most scholars with some exceptions. "Classic» approach of outlining principles of consent, impartiality and non-use of force was favored by Lindsey Cameron (Cameron, 2017, p. 60), Dag Nyström (Nystöm, 2015, p. 39), Christine Gray (Gray, 2016, p. 201), Lise Morje Howard (Howard, 2019, p. 4), Hitoshi Nasu (Nasu, 2009, p. 17), Dieter Fleck (Fleck, 2014, p. 219). Each of them outlines and points out the same three principles that were mentioned.

But at the same time there are other approaches to interpret the principles of peacekeeping.

Under Yoram Dinstein «the two special attributes of a peacekeeping force are that (i) it is established and maintained with the consent of all the States concerned; and (ii) it is not authorized to take military action against any State» (Dinstein, 2005, p. 308). It can be seen the Dinstein doesn't outline «impartiality» as one of the essential principles of peacekeeping. Analysing the relevant article of mentioned author, in point of view of present writer, such «exclusion» of impartiality from the list of principles is explained by the jurisprudence of ICJ applied by Dinstein, i.e. Advisory opinion on 20 July, 1962 in case «Certain expenses of the United Nations» (Certain expenses, 1962, par. 170-177) in the one hand and that fact that reasonably the peacekeeping forces are acting impartial by default because of having strict control and command due to the task indicated by the SC in the other (Dinstein, 2005, p. 311).

Such position of Yoram Dinstein can be criticised over the relevant peacekeeping practice and by Report of the High-level Independent Panel on Peace Operations on uniting our strengths for peace: politics, partnership and people as well (Report, 2015).

Another point of view shows Osamu Yoshida. He offers broader approach to the principles of peacekeeping. It consists of five principles: (i) existence of a truce or cease-fire; (ii) consent of all parties to the conflict or establishment of the operation at the request of the parties; (iii) impartiality or neutrality (no involvement in the conflict, no favouring of one party over the other); (iv) use of force only in self-defence or if hindered by force to fulfil the mandate; and (v) personnelofpeacekee pingoperationsmusttakeordersonlyfromthecommander of the operation and not from the organs of the sending state (Yoshida, 2013, p. 116).

Yoshida explains outlining the «extra-principle» of cease fire in the list of «five principles of peacekeeping» in that way that if the cease fire in the conflict zone doesn't exist thus the peacekeeping mission would be endangered and the principle of non-use of force could be violated. Also Yoshida argues that if the peacekeeping mission faced a military issue the mission therefore would be enforcement and not peacekeeping because the first goal of it would be the military aspect of conflict (Yoshida, 2013, p. 116). Actually, that is why Japan decided to limit its participation in traditional peacekeeping operations (Shigeru, 1999, p. 29).

Moving closer to the point of view of Yoshida, it can be criticised as well as previous of Dinstein. First, it has to be noted that the $5^{\text {th }}$ principle, which means that peacekeeping forces shouldn't be under the command or control of host state, is senseless because it duplicates the $3^{\text {rd }}$ principle of «impartiality» which has the same ratione mataerie as the Yoshima's $5^{\text {th }}$. Second, the $1^{\text {st }}$ principle of «cease fire existence» is also contrary to the $4^{\text {th }}$ principle, which bans use of force only whereas it is needed for self-defence and for maintaining the mandate. In point of view of present writer argument that non-existence of cease fire could violate the essential task of peacekeeping is not reasonable.

Thus, the «classic» list of the principles of peacekeeping to be observed in present article: (i) Consent of the parties; (ii) Impartiality; (iii) Non-use of force.

(I) The principle of consent of the parties. As it was said before, the principle of the consent of the parties is recognised as fundamental by all mentioned scholars and the practice of the UN. 
United Nations peacekeeping operations are deployed with the consent of the main parties to the conflict. This requires a commitment by the parties to a political process and their acceptance of a peacekeeping operation mandated to support that process. The consent of the main parties provides a United Nations peacekeeping operation with the necessary freedom of action, both political and physical, to carry out its mandated tasks. In the absence of such consent, a United Nations peacekeeping operation risks becoming a party to the conflict; and being drawn towards enforcement action, and away from its intrinsic role of keeping the peace (Principles and Guidelines, 2008, par. 63).

The NATO's joint doctrine on issue of the principle of consent says: «the level of consent given by the major conflicting parties' leadership reflects the degree of acceptance of external intervention in what is effectively an internal or regional dispute. The type of peace support effort is partly determined by the level of consent given by the main parties to an intervening force» (Allied Joint Doctrine, 2014, par. 0228).

Following Yoram Dinstein, the concept of consent has stirred up a number of thorny problems in its application, although it is still accepted in principle as a condition precedent for the stationing of a peacekeeping force (Dinstein, 2005, p. 308).

Lindsey Cameron says that the UN doctrine does not accept that consent legally requires that a host state agree to the composition of the force, but the host state's consent to the composition of the force will play an important role in the UN's decision-making (Cameron, 2017, p. 66). Notably, however, on a purely legal level, the requirement that a host state consent to the force remains necessary to ensure that the UN respects Article 2 (7) of the Charter (Cameron, 2017, p. 64). This is clearly recalling with cited Principles and Guidelines of the UN Peacekeeping Operations, that «<.. > peacekeeping operation risks becoming a party to the conflict».

Hitoshi Nasu favours this statement appealing: «Although peacekeeping operations are often based on a cease-fire or peace agreement, the UN's involvement without consideration of the nature of the agreement in question ultimately risks undermining its own legitimacy and credibility as well as endangering peacekeepers deployed on the ground» (Nasu, 2009, p. 23).

Tarcisio Gazzini says that «the consent of all concerned parties provides an adequate legal basis for peace-keeping operations carried out by regional organizations» (Gazzini, 2003, p. 253).

The peacekeeping operations undertaken by NATO in former Yugoslavia, Albania and Macedonia satisfy by any standard the consent requirement (Gazzini, 2003, p. 253). In the case of former Yugoslavia, in particular, all the belligerent parties - whose international legal status was at the time controversial - validly expressed their consent at the London Conference (Resolution 781/1992, 1992). In the case of Albania and Macedonia, the operations were not only requested by and carried out in co-operation with the respective governments; they were also directed at involving non-governmental groups or entities in the peace building and democratization process.

Here arises the relevant question: what if a host state withdraw it consent after the peacekeeping operation has begun? Both Cameron (Cameron, 2017, p. 66) and Dinstein argues that such withdraw would effect on operation. In example of peacekeeping mission in Iraq, Dinstein explains that while, as a rule, a withdrawal of prior consent by a Host-State would terminate a peacekeeping operation, Resolution 689 (1991) (Resolution 689/1991, 1991) proclaimed categorically that the deployment of UNIKOM «can only be terminated by a decision of the Council» (Dinstein, 2005, p. 308).

But, nevertheless, the issue remains unclear as Ian Bronwlie wrote that «because sovereign States are in principle free to dispose of their territory, they also have the right to dispose of their exclusive right to use that territory, and thus to allow military operations of other States on their State territory. As long as that consent is genuine, the prohibition of the use of force does not apply, therefore, to military actions of other States' forces on the territory of a State whose government has consented to those operations» (Brownlie, 2003, p. 320).

Nevertheless, the Principles and Guidelines of the UN Peacekeeping Operations stresses that «the complete withdrawal of consent by one or more of the main parties challenges the rationale for the United Nations peace-keeping operation and will likely alter the core assumptions and parameters underpinning the international community's strategy to support the peace process» (Principles and Guidelines, 2008, par. 65). 
(II) Principle of impartiality. The impartial character of peacekeeping operations, nonetheless, serves to distinguish these operations from those having a defensive purpose in the sense of article 51 of the UN Charter, where the force deliberately takes sides in the confrontation or conflict (Gazzini, 2003, p. 252).

According to the Principles and Guidelines of the UN Peacekeeping Operations, United Nations peacekeeping operations must implement their mandate without favour or prejudice to any party. Impartiality is crucial to maintaining the consent and cooperation of the main parties, but should not be confused with neutrality or inactivity. United Nations peacekeepers should be impartial in their dealings with the parties to the conflict, but not neutral in the execution of their mandate (Principles and Guidelines, 2008, par. 67).

It should be noted that revolutionary report on peacekeeping of 2000 known as «The Brahimi Report» has insisted that impartiality must «mean adherence to the principles of the Charter and to the objectives of the mandate that is rooted in these Charter principles» (Report, 2000, par. 50).

It is needed to add that the further report of the High-level Independent Panel on «Peace Operations on uniting our strengths for peace: politics, partnership and people» (Report, 2015) of 2015 doesn't pay so much attention to the principle of impartiality, but rather moves forward to the issue of «neutrality» (more detailed - infra).

Talking on the current issue of impartiality, Lindsey Cameron states that impartiality would appear to mean that an operation does not take sides. A peacekeeping force with a robust mandate may use military force against an organized armed group in order to enforce its mandate - even if that use of force may lead it to become a party to a conflict. What may reasonably allow such uses of force to continue to garner approval as «impartial» is that they are taken in an effort not to actually defeat a party to a conflict, but rather to enforce a mandate, such as protecting civilians (Cameron, 2017, p. 77).

Dieter Fleck, at the same time, writes that «for any peace operation the impartiality of peace forces towards conflicting parties is essential for providing convincing assistance in the peace process. The impartiality of peacekeepers is challenged in the case of non-compliance by the host government or factions in the receiving state with existing obligations and commitments» (Fleck, 2014, p. 220).

Hitoshi Nasu, calling the principle of impartiality as «neutrality», says that it suggests the apolitical character of a peacekeeping operation, mandating peacekeepers to hold no prejudice towards participants in a conflict and not to influence the course of events. Generally speaking, Nasu is slightly mixing «neutrality» and «impartiality» and outlines that this «mix» should rather be identified as a «neutrality» (Nasu, 2009, p. 24).

Nevertheless, such point of view has to be criticised. For example, Lindsey Cameron stresses that «In any case, respect for the principle of impartiality is tricky and requires a sophisticated understanding of the parties and circumstances. Impartiality must not be confused with neutrality, if neutrality is understood to mean passivity» (Cameron, 2017, p. 76).

Dieter Fleck takes the same side of a dispute saying that «for the Security Council neutrality is not a viable option, as the world organization cannot be neutral to a threat to the peace, breach of the peace, or act of aggression. This has been confirmed in UN practice in the case of states being denied membership in the United Nations for adhering to a policy of neutrality without reservation» (Fleck, 2014, p. 220).

Mentioned Fleck's statement on the importance of the distinguish of «impartiality» and «neutrality» grounds on the comparative approach applying similar provisions of the international humanitarian law. Thus, for this purpose Fleck takes the Fundamental Principles of the International Red Cross and Red Crescent Movement. According to it, impartiality and neutrality must, indeed, be kept distinct from one another. For the Red Cross, impartiality serves to relieve the suffering of victims by concentrating on their needs and giving priority to the most urgent cases of distress. Neutrality, as an additional Red Cross principle, which is not applicable to UN peace operations, excludes taking sides in hostilities or engaging in controversies of a political, racial, religious, or ideological nature. A neutral person refuses to make a judgement whereas the one who is impartial judges a situation in accordance with pre-established rules (Fundamental Principles, 1965).

Also it should be added that «The Brahimi Report» has rightly emphasized that impartiality of peacekeepers should not be misconceived as «neutrality or equal treatment of all parties in all cases for all time» (Report, 2000, par. 50). 
The NATO's joint doctrine also put a light on this issue arguing that «impartiality must not be confused with neutrality. Impartiality requires a degree of judgement against the principles outlined above, to implement the mandate.Neutrality, on the other hand, promotes a passive approach and consequently could limit the contribution made by the peacekeepers. The conduct of the peacekeeping forces during peace support should be impartial in relation to the actors but should never be neutral in the execution of the mission» (Allied Joint Doctrine, 2014, par. 0230/c).

(III) Principle of non-use of force. In its Advisory Opinion of 20 July, 1962 in case «Certain expenses of the United Nations» the ICJ acknowledged that peacekeeping forces cannot be authorised by the SC to use force against any state (Certain Expenses, 1962, par. 170-177).

Yoram Dinstein opens up this interpretation discussion saying that «in essence, peacekeeping forces are not designed for combat. Nevertheless, it has always been understood that they are entitled to defend themselves. This specific right of self-defence, applicable to peacekeeping forces, should not be confused with the much broader right of self-defence vested in States» (Dinstein, 2005, p. 308).

Looking at the well-established doctrine of peacekeepers' right to use force in self-defence and in defence of the mandate, the question is what the limits to such a mandate are. Using force in defence of the mandate is not the same as enforcing peace. Peace enforcement may, in contrast to peacekeeping, involve the use of force at the strategic international level, which is normally prohibited for Member States under Art 2 (4) of the Charter unless authorized by the UNSC (Nyström, 2015, p. 42).

Under the Principles and Guidelines of the UN Peacekeeping, a United Nations peacekeeping operation should only use force as a measure of last resort, when other methods of persuasion have been exhausted, and an operation must always exercise restraint when doing so. The ultimate aim of the use of force is to influence and deter spoilers working against the peace process or seeking to harm civilians; and not to seek their military defeat (Principles and Guidelines, 2008, par. 73).

Hitoshi Nasu points that «the non-use of force is a logical consequence of the doctrines of consent and neutrality. As long as it relies on the consent of a sovereign state, the peacekeeping force cannot resort to military action against the state. Any instances of using armed force will have an impact upon the military and political balance between the belligerent parties» (Nasu, 2009, p. 25).

Under the NATO's joint doctrine, the use of force should be restricted to self-defence and defence of the mandate only, such as the protection of civilians under the imminent threat of violence. The authority to use force in peace support will be provided by the legal basis and reflected in the mission's ROE. The political and military will of the Alliance to use force may help provide credible deterrence in order to persuade major conflicting parties to negotiate a ceasefire or peace settlement, or to deter them and other actors from adopting spoiling behaviour towards the peace process (Allied Joint Doctrine, 2014, par. 0231).

It has to be noted that following views on the principle of non-use of force in peacekeeping are mostly arguable that if the use force in peacekeeping mission is enormous, thus such mission would become not peacekeeping but peace-enforcement which contradicts with the article 2 (4) and 2 (7) of the UN charter (UN Charter, 1945).

Also another question regarding this issue could be arisen: is it correct to assume that the attack on the peacekeepers, including the representatives of military unit of definite state, could cause the application of the right to self-defence under the article 51 of the UN Charter and article 5 of North Atlantic Treaty? Is it possible in given situation that the inherent right of self-defence of peacekeepers under the principle of «non-use of force» would transform into the self-defence in meaning of article 51 of the UN Charter?

In opinion of present writer, the answer should be negative because under the notion of «armed attack» as a precedent to the self-defence it should be acted against the integrity, political sovereignty and its security when the attack on peacekeepers has another intended aims that contradicts with the concept of self-defence.

Conclusions. As a result of previously observed legal practice and academic thoughts on the issue of principles of the peacekeeping, with the coherence to the topic of current article on the NATO's peacekeeping activities, it can be concluded that the peacekeeping activities of NATO as a regional organisation in aspect of the article 53 of the UN Charter should follow tree fundamental principles, which at the same time have to be the key requirements for legal actions. These principles are: 
(i) consent; (ii) impartiality and (iii) non-use of force. The key idea of given principles of peacekeeping regarding the NATO is that that only on grounds of their fulfilment could the Alliance reach its goals as well as goals of the UN Charter in most effective way without violating international law. Such fulfilment of the UN practice and application of jus cogens are in strong connection to the provisions of the North Atlantic Treaty (North Atlantic Treaty, 1949), which indicates the values of the UN Charter as essential for the Alliance. Given approach on the principles of the peacekeeping is quite certain enough because of subsequently evolution of NATO's legal framework in joint doctrines. Also this shows the essential role which unified approach to the legal aspects of activities plays in Alliance.

\section{References}

United Nations Charter, 26 June 1945 [entered into force 24 October 1945]. URL: https://www.un.org/en/ charter-united-nations.

The North Atlantic Treaty, Washington D.C., 4 April 1949 [entered into force 4 April 1949]. URL: https://tinyurl.com/ycrllhdo.

Allied Joint Doctrine for Non-Article 5 Crisis Response Operations, AJP-3.4 (A), entered to force on 15 October, 2010. URL: https:// tinyurl.com/rubnlzk.

Allied Joint Doctrine for The Military Contribution to Peace Support, AJP-3.4.1 (A), entered to force on 2 December, 2014. URL: https:// tinyurl.com/tyr8arg.

Fundamental Principles of the International Red Cross and Red Crescent Movement, proclaimed by the $20^{\text {th }}$ International Red Cross Conference (Vienna, 1965).

Certain expenses of the United Nations (Article 17, paragraph 2 of the Charter), Advisory Opinion of 20 July 1962 : I.C.J. Reports 1962, P. 151.

Report of the Panel (2000) on United Nations Peace Operations. UN Doc A/55/305.

Report of the High-level Independent Panel (2015) on "Peace Operations on uniting our strengths for peace: politics, partnership and people". UN Doc A/70/95.

Resolution Concerning the UN Iraq-Kuwait Observation Mission. 689 (1991) / adopted by the Security Council as its 2983rd meeting, on 9 April 1991. UN DOC S/RES/ 689 (1991).

Resolution concerning flight restrictions in the airspace of Bosnia and Hercegovina, 781 (1992) / Adopted by the Security Council on its 3122nd meeting, on 9 October, 1992. UN Doc S/RES/781.

United Nations Peacekeeping Operations : Principles and Guidelines. International Peacekeeping. 2008. № 15(5). P. 742-799.

Brownlie Ian. Principles of public international law. $6^{\text {th }}$ ed. Oxford : Oxford University Press, 2003.

Cameron L. The Privatization of Peacekeeping: Exploring Limits and Responsibility under International Law. Cambridge : Cambridge University Press. 2017.

Dinstein Y. War, Aggression and Self-Defence. Cambridge : Cambridge University Press, 2005.

Fleck Dieter. The Law Applicable to Peace Operations. The Oxford handbook of international law in armed conflict (Oxford handbook). Oxford: Oxford University Press, 2014. P. 206-247.

Gazzini T. NATO's Role in the Collective Security System. Journal of Conflict and Security Law. 2003. № 8(2). P. 231-263. Gray C. The 2015 Report on Uniting Our Strengths for Peace: A New Framework for UN Peacekeeping? Chinese Journal of International Law. 2016. № 15(1). P. 193-213.

Howard L. Power in Peacekeeping. Cambridge : Cambridge University Press, 2019.

Nasu H. International Law on Peacekeeping: A Study of Article 40 of the un Charter. $1^{\text {st }}$ ed. Leiden : BRILL, 2009. Nyström D. The UN mission in Congo and the basic principles of peacekeeping: Revolution or evolution? Stockholm : Stockholm University, 2016.

Shigeru Kozai. UN Peacekeeping and Japan: Problems and Prospects. Japan and International Law: Past, Present and Future: International Symposium to Mark the Centennial of the Japanese Association of International Law. International Law in Japanese Perspective. The Hague : Kluwer Law International, 1999. Vol. 5. P. 29-42.

Yoshida Osamu. Japan's efforts in United Nations peacekeeping operations: from the perspectives of international law and foreign policy-making. Northeast Asian Perspectives on International Law: Contemporary Issues and Challenges.) Leiden : BRILL, 2013. P. 113-130.

\section{Summary}

Oleksiuk N. M. Principles of peacekeeping in NATO's legal framework. - Article.

The article deals with the issue on the principles of peacekeeping activities of NATO as the international organization maintaining the challenges of world's peace and order in particular regions. It puts a light on a divertive coherence of legal practice of international organizations, e.g. UN and NATO and scholar 
thoughts on given problem of identification and application of the principles of peacekeeping. It is noted that there is an academic debate regarding the number of principles between Lindsey Cameron, Dag Nyström, Christine Gray, Lise Morje Howard, Hitoshi Nasu, Dieter Fleck, who offer so called "classic" approach on the one hand, and Yoram Dinstein and Osamu Youshida, who have an opposite opinion of their approach of outlining the principles of peacekeeping. The article emphasizes the main key ideas of given scholar views that are unified for each approach in general. The article analyses given academic approaches on the issue of research and outlines the list of the principles of peacekeeping, which are observed: (i) Consent of the parties; (ii) Impartiality; (iii) Non-use of force. Also article gives the definition and gives the explanation to each of them. It is explained the negative consequences in case of breaching given principles. The relevant examples of such in experience of peacekeeping activities are given. Examination of these principles is provided under the jurisprudence of the International Court of Justice and legal practice of the UN, which is fundamentally primal to any kind of peacekeeping activities - of the UN or other international organizations. It is observed the relevant NATO's practice of peacekeeping and NATO's legal acts as well. It is pointed on the importance to follow these principles because of the provisions of the international customary law in general and the UN Charter in particular. The article concludes that the key idea of given principles of peacekeeping regarding the NATO is that that only on the grounds of their fulfilment could the Alliance reach its goals as well as goals of the UN Charter in most effective way without violating international law. It is stressed that given approach on the principles of the peacekeeping is quite certain enough because of subsequently evolution of NATO's legal framework in joint doctrines.

Key words: NATO, peacekeeping activities, principles, consent, impartiality, non-use of force.

\section{Анотація}

Олексюк Н. М. Принципи миротворчої діяльності у правовому полі НАТО. - Стаття.

Стаття стосується проблеми принципів миротворчої діяльності НАТО як міжнародної організації, що врегульовує виклики щодо світового миру та порядку в певних регіонах. Висвітлюється нерозривний зв' язок між юридичною практикою міжнародних організацій, як-от Організація Об'єднаних Націй i HATO, з одного боку, та наукових поглядів щодо визначення та застосування принципів миротворчої діяльності, із другого. Акцентовано на існуванні академічної дискусії щодо кількості принципів миротворчої діяльності між Ліндсей Кемерон, Дагом Ністрьомом, Крістін Грей, Ліз Говард, Хітоші Насу, Дітером Флеком, які пропонують «класичний» підхід щодо принципів миротворчості, з одного боку, та Йорамом Дінштайном і Осаму Йошидою, які мають протилежний погляд щодо даної проблеми, із другого. У статті виокремлено ключові ідеї згаданих академічних поглядів, які є спільними для цих наукових підходів. У статті проаналізовано згадані академічні підходи щодо принципів миротворчості та виокремлено перелік принципів, що досліджуються, як-от: 1) згода; 2) неупередженість; 3) незастосування сили. Також у статті дається визначення та пояснення кожному з даних принципів. Наведено приклади негативних наслідків, які можуть настати за недотримання даних принципів. Відповідні приклади таких у миротворчій діяльності наведено. Дослідження вказаних принципів проводиться на основі практики Міжнародного суду Організації Об'єднаних Націй та Організацієї Об'єднаних Націй, які $є$ фундаментально первинними для будь-якої миротворчої діяльності - як Організації Об'єднаних Націй, так і інших міжнародних організацій. У статті зроблено огляд відповідної миротворчої практики НАТО і юридичних документів Альянсу. Акцентовано на важливості дотримання даних принципів у зв'язку з положеннями звичайного міжнародного права загалом та норм Статуту Організації Об'єднаних Націй зокрема. Підсумовано, що ключова ідея застосування даних принципів у діяльності НАТО полягає в тому, що Альянс може досягнути поставлені перед ним Статутом Організації Об'єднаних Націй цілі ефективним способом лише за дотримання даних принципів. Загалом зауважено, що підхід до принципів миротворчості, застосований у правовому полі НАТО, досить чітко врегульований і зрозумілий, зважаючи на розвиток та вдосконалення правової доктрини Альянсу.

Ключовi слова: НАТО, миротворча діяльність, принципи, згода сторін, неупередженість, незастосування сили. 